Review Article

www.ijrap.net

\title{
PHARMACOLOGY OF GUGGULU WITH SPECIAL REFERENCE TO CONCEPTUAL PHARMACOGNOSY IN VEDAS
}

\author{
Gopal C.Nanda*
}

Assistant Director (Scientist-4) \& Incharge, National Research Institute of Ayurvedic Drug Development, Bharatpur, Bhubaneswar-3, Odisha, India

Received on: 06/01/13 Revised on: 10/02/13 Accepted on: 12/03/13

\author{
*Corresponding author \\ E-mail: vdgnanda@gmail.com \\ DOI: $10.7897 / 2277-4343.04329$ \\ Published by Moksha Publishing House. Website www.mokshaph.com \\ All rights reserved.
}

\section{ABSTRACT}

Guggulu a very known and common name in the field of Ayurvedic practices which is used as an important medicine for treating a lot of diseases. The drug having a lot of potency described in Ayurveda with pharmacological action tested with its present Research and Development study. It should be wiser to establish a platform for the next generation to understand the modules of Guggulu preparations and administrations. Though guggulu is an established drug but the phytochemical and Pharmacological R and D study have found the merits and demerits of the guggulusterone, the active principle of the drug Guggulu. However, the relationship between the effect of Guggulu both in Ayurveda and modern science has been found similar. Efforts have been made in this paper to study the relationship of Guggulu starting from Veda to present Lab. facts.

Keywords: Guggulu, Pharmacognonsy, Ayurveda

\section{INTRODUCTION}

Existence of Ayurved is believed to be pre-historic due to fundamental concept of Panch Mahabhut. No doubt the system of knowledge based on the natural sciences continues with unaccountable truth and evidence.

Ayurveda is the extended version of Atharv veda for which it is being named as "Atharvani" and starting from Trisutra (Hetu Linga Ausadha) expanded to the whole nature and it's products. Ayurveda has identified and incorporated all the naturals as medicine having their eternal potency due to value added properties like Haritaki, Bibhitaki, Amalaki, Guduchi etc. Guggulu is one such natural drug which is even considered as Divya Ausadhi by rishis/ancestors.

\section{History}

Guggulu is one of the ancient Ayurvedic drug described in Atharvvaveda (2000 B.C.). Guggulu posses the specific qualities as described in Atharvaveda.

"aa natam yaksma arundhate nainam sapatho asnute yam bhesajashya gugguloh surabhirgandho asnute viswen cha tasmad yakshma mruga asvoiverate yad guggulu saindhavam yad yasyansi samudriyam ubhayoragrabham namasma aristatataye"

(Atharveda:Khand:29:Su- 38)

The above version indicates that Guggulu is the best medicine, it has an aromatic order. It removes the diseases because it develops through the rays of hot sun on specific circumstances. Further it denotes-

"marubhumishu jayante prayashah purapadapah bhanourmayukheih santaptah grishme munchati guggulu"

It means guggulu automatically exudates from the free when exposed to sun specifically in desert areas. It is indicated in Yakshma which is the synonym of the term disease as -

"rogapapma jwarovyadhi vikaro dukhamamaya yakshmatankam gadavadhah sabdah paryayavachinah"

(Amarkosh)

The disease can not appear in sunlight. So it removes the disease like a deer that runs away on seeing the horse. It appears from the above citation that Guggulu is a potent drug for eliminating all sorts of diseases.

\section{Medicinal potency in classic}

From the above reference it appears that guggulu was considered as an important drug during Vedic period. Apart from this, they have also specified that guggulu mixed with salt removes all the diseases along with complications. It is a fact that veda describes the inner quality for managing all sorts of diseases where in the later period the seers of Ayurveda have developed some specifications of the diseases with their varieties. Maharishi Charak has specified more accurately as

$$
\text { "guggulurmedonilaharanam” (Ch.Su.25) }
$$

The citation defines that all sorts of meda (lipid) and Anila (Vata or neurological) disorders are managed, specifically Pravrudha Meda (lipid disorder) and Pravrudha vata (neurological disorder) are cured by guggulu only.

However, a lot of descriptions not only in vrihatrayi rather contemporary and in later works have described the unlimited potency of Guggulu. If we analyse, we find a lot of diseases described in Ayurveda are managed properly by Guggulu. According to Susruta Samhita, Guggulu cures obesity, liver dysfunctions, internal tumors, malignant sores, ulcers, urinary complaints ${ }^{1}$ 
fistula-in-ano, intestinal worms, leucoderma, sinus, oedema and paralytic disorders. It is also considered as cardiac tonic (Hrudya). But, all these diseases are not cured only by guggulu itself rather combination of other drugs are added to potentiate against a group of diseases and accordingly a variety of Guggulu preparations came out in later period as- Yograj Guggulu, Maha Yograj Guggulu, Kaisore Guggulu, Kanchnar Guggulu, Vatari Guggulu, Sunthi Guggulu, Amruta Guggulu, Lakyadi Guggulu, Katuki Guggulu, Pushkar Guggulu, Trifala Guggulu, Trayodasanga Guggulu., Saptavinsati Guggulu, Panchtikta Ghrit Guggulu, Navak Guggulu and Medohar Guggulu etc.

\section{Identity and Modern pharmacological evidence}

As on today, the modern science has also confirmed the multi-dimensional activities of guggulusterone, the extract of the gum resin of Guggulu (Commiphora wightii). The oleo-gum-resin of guggulu is a very complex mixture of gum, minerals, essential oils, terpenes, sterols, sterones and several other unknown compounds ${ }^{2}$. Gum guggulu obtained from the tree Commiphora wightii (Arnott.) Bhandari (Syn. Commiphora mukul) belongs to the family Burseraeceae and is found extensively in the dry regions of the Indian sub-continent mainly India, Pakistan and Bangladesh. It is a shrub with thorny branches.

The dry gum resin obtained from the bark of Guggulu is a mixture of diterpenes, sterols, steroids, esters and higher alcohols $^{3}$. The active components of the plant are the guggulusterones $\mathrm{E}$ and guggulusterone $\mathrm{Z}$. There are plant sterols with a high degree of human bioactivity which have been shown to affect many biological processes. Besides guggulusterones, sterols have also been isolated from guggulu and evaluated for their pharmacological properties. Some of these properties are antidiabetic, antibacterial and anti-inflammatory activities etc. It is involved in the regulation of bile-acid, cholesterol, triglyceride, and glucose metabolism.

Use of the guggulu preparations have been experimented as antiinflammatory Hypolipidueric, Hepatoprotective, cardio-protective, Antioxidant, anticancer, Anti osteoclastogenic, thyroid stimulatory, Antiarthritic, Antiosteoporotic, Antihelminthic, Anti-acne, and Antiobesity like properties. It is also used in oxidative stress- myocardial ischemia and neurodegenerative diseases and as a potential antidementia drug and cognitive enhancer ${ }^{4}$.

\section{Pharmaco-vigilance and Toxicity}

The bioavailability, pharmacokinetic and pharmacodynamic effect of Guggulu in human are not upto content by modern method of research till today but it appears that Guggulu can affect the bio availability of other drugs 5 . The safety and long term use of guggulu has not been evaluated in a clinical setting but it appears to be devoid of acute, sub acute or chronic toxicity as studied on rats, $\operatorname{dogs}^{6}$ and monkeys. So far Ayurvedic phamacognosy is concerned it is mentioned that-
"Sa navo vrumhano vrushyam puranaswati lekhanah"

That if old guggulu is used for a prolonged period it may cause lypolysis action resulting to emaciation and the fresh Guggulu has lipogenetic action. Further reference says-

"timira vadana sosha klivata karsyamohan, Samala sithila bhavam deha raukhyam cha, Tasmat rajanichar nishevi syat na rogeshu amishu"

(ASU 49/178)

Means it can cause loss of facial glossy, impotency, wasting condition, vertigo/dizziness, dryness of skin etc. if continued for a prolonged period.

So far modern parameter and Ayurvedic references are concerned Guggulu or guggulu-sterone is generally safe in short-term use although side effects such as skinrashes, diarrhoea and nausea have been reported. No significant side effects have been observed on renal function, liver functions, haematological parameters, or electrolytes as evident from records. Guggulu has a long history of safe use in Ayurvedic system of medicine however; it should be used cautiously in combination with other drugs, as it may modulate the activity of drug metabolizing enzymes ${ }^{7}$.

\section{CONCLUSION}

Every drug has got it's own mode of action through inherited potency generated from nature and it is also very difficult to establish by limited parameters. Ayurveda believes in Rasa, Guna, Veerya, Vipaka and Prabhava which were known to the ancestors of Ayurveda and accordingly they have brought out a lot of guggulu preparations for variety of diseases. Time has come to revalidate those evidence based formulae to restore the healthy conditions of human being. It is natural and we should get closer to nature to understand.

\section{REFERENCES}

1. Skoog DA, West DM, Holler Fj. Fundamentals of Analytical Chemistry, Saunders College Publishing, USA, $7^{\text {th }}$ edition, 1996.115 .

2. Sane RT. Standardization Quality control and GMP's for Herbal Drugs, Indian Drugs, 2002;39(3):184-190.

3. P.V. Sharma, Drugyaguna Vijnana, Chakhamba Bharati Academy, Varanasi,2001, Vol.-II

4. Pingale SS, Pingale MS and Pokkarkar RD, Stability study of a herbal drug, Pharmacologyonline Newsletter 2008;1:20-23

5. Indian Herbal Pharmacopoeia, pub. Regional Research Laboratory, Jammu Tawi and Indian Drug Manufacturer's Association, Mumbai, 1999;2:85-92

6. Chopra RN, Chopra LC, Varma BS, Supplement to Glossary of Indian medicinal plants, publication and Information Division, CSIR, New Delhi, Indian, 1969.

7. Asolkar LV, Kakkar KK, Chakra OJ. Second supplement to glossary of Indian medicinal plants with active principles. Part1(AK). Publication and Information Division, CSIR, New Delhi, India, 1992

Cite this article as:

Gopal C.Nanda. Pharmacology of guggulu with special reference to conceptual pharmacognosy in Vedas. Int. J. Res. Ayurveda Pharm. 2013;4(3):452-453 